\title{
Environmental Regulations, Environmental Subsidies and Enterprise Investment for Environmental Protection: Evidence from Pollution Enterprises of China
}

\author{
Chunwei Han
}

School of Accounting, Henan University of Engineering, Zhengzhou 451191, China

†Corresponding author: Chunwei Han; huehan@126.com

Nat. Env. \& Poll. Tech.

Website: www.neptjournal.com

Received: 05-06-2021

Revised: 28-06-2021

Accepted: 09-07-2021

\section{Key Words:}

Environmental regulations

Environmental subsidies

Environmental protection

Pollution enterprises

Propensity matching score

\begin{abstract}
Environmental protection concerns the global and long-term development of the social economy. The negative effects of production and management activities of pollution enterprises on the environment attract more and more attention from the whole society. The government is not only continuously strengthening production regulation, responsibility monitoring and establishment of rules and regulations of pollution enterprises, but also increasing supports to environmental-friendly development of pollution enterprises. To explore influences of environmental regulations and environmental subsidies on enterprise investment to environmental protection, influences of environmental subsidies under environmental regulations were discussed through the propensity matching using data of listed enterprises in China's pollution industry from 2013 to 2019. Results demonstrate that environmental subsidies promote the growth of enterprise investment to environmental protection significantly and environmental regulations are the primary influencing factor. According to heterogeneity analysis, environmental subsidies have significant positive effects on the investment in environmental protection of state-owned enterprises and private enterprises. The quantity and amplitude of investment in environmental protection of state-owned enterprises are more prominent. Environmental subsidies significantly promote investment in environmental protection of enterprises where senior executives have a technological background, but they have no significant influences on enterprises where senior executives have no technological background. Conclusions have some policy significance: government urges pollution enterprises to increase investment in environmental protection and pursue sustainable development from perspectives of incentives (increasing economic subsidies) and pressure (developing collaborative effect of environmental regulation).
\end{abstract}

\section{INTRODUCTION}

Environmental pollution has become a common problem around the whole world. As an important participant of the market economy and major releaser of pollutants, pollution enterprises shall increase investment in environmental protection and assume environmental protection responsibilities while pursuing economic development. The government of China (GOC) has promoted environmental problems to the strategic level. On one hand, GOC is regulating the pollution industry greatly and eliminating enterprises that fail to meet the industrial access conditions strictly. On the other hand, GOC provides pollution enterprises great supports for investment in environmental protection and practices in sustainable development.

In studies on environmental governance, the government is a power that cannot be ignored. According to classical documents, relevant research conclusions about the influences of government on enterprise investment in environmental protection are inconsistent. Some view government as the "hand of support", while some view it as the "hand of pillage". These involve multiple aspects of reasons. Among them, support and punishment are two intervention factors that shall be considered simultaneously and the government's preferences to policies of environmental subsidies to enterprises shall not be ignored (Bai et al. 2019, Boeing 2016). For this reason, influences of environmental subsidies on investment of pollution enterprises to environmental protection under environmental regulations were discussed from the above three factors. Moreover, a heterogeneity analysis of the ownership of enterprises and technological background of senior executives was carried out, which provided decision supports to environmental protection policies for enterprises with heavy pollutions.

\section{PAST STUDIES AND HYPOTHESIS DEVELOPMENT}

According to the environmental externality theory, the environment is a kind of special economic output that has externality and uncertainty. Due to the existence of externality, environmental pollution cost caused by the production activities of enterprises is assumed by the society rather 
than enterprises. Enterprises often prefer tangible current benefits. From the perspective of sustainable development, the environmental output of enterprises involves the balance between future benefits and current benefits, and the future has some uncertainty. Due to objective existences of market failures like externality and uncertainty, enterprises neglect environmental costs to acquire short-term benefits, thus causing environmental deterioration. Hence, the government has to participate in its governance over environmental problem often integrates supports and punishment.

As compulsive environmental governance means, environmental regulations require enterprises to invest in environmental protection; otherwise, they will be punished according to laws. According to the principle of Environmental Protection Law of China that "whoever causes pollution is responsible for treatment", pollution enterprises which are the main source of environmental pollution must assume responsibility for environmental protection and invest in environmental protection. Nevertheless, the society is difficult to get extra losses of environmental pollution from the responsible enterprises since the environment has a special externality of classical public products. Moreover, pollution governance focuses on social benefits and enterprise investment in environmental protection cannot bring short-term benefits. Therefore, enterprises are unwilling to invest in environmental protection because they pursued profits. Besides, enterprises are generally facing financing constraints of the capital market. Therefore, enterprises are passive and cooperative to environmental protection behaviors even under strict environmental regulations, so they generally have an insufficient investment in environmental protection (Xie, $\mathrm{Z}$. H. et al., 2018). For this reason, GOC has arranged a lot of environmental subsidies and encouraged pollution enterprises to have an investment in environmental protection.

Generally speaking, environmental subsidies provide direct capital supply to pollution enterprises and relieve internal financing pressure. Moreover, environmental subsidies transmit the approval effect of government to the external environment, which are conducive to attracting external institutional investors (e.g. banks) and expanding financial channels for environmental protection activities in enterprises indirectly. On product market, environmental subsidies beautify images and improve the social reputation of enterprises, which are beneficial to expand market demands and improve the supply-marketing relations. In other words, environmental subsidies not only provide capital to enterprises directly or indirectly but also improve the production element environment. Therefore, environmental subsidies can stimulate the investment of enterprises in environmental protection activities and realize benign interaction between enterprise production and economic sustainable development. Environmental subsidies also bring enterprises stronger pressures of government regulation and supervision (Li et al. 2017). Punishment information for violating environmental regulations may cause negative economic losses and reputation losses. This promotes enterprises to improve the legality of environmental behaviors by increasing investment in environmental protection, especially for those environmental-sensitive pollution enterprises sensitive (Pellegrino et al. 2012).

In a world, the government provides subsidies to enterprises and encourage them to increase investment in environmental protection. In regions with heavy environmental pollution, punitive environmental regulations and supportive environmental subsidies are often applied together (Zhang 2013). This is the called "hand of support". Nevertheless, the "hand of pillage" cannot be neglected. This is because the government might seek renting by the right of handmade, or is manipulated by some interest groups to pursue private benefits. In this study, some competitive hypotheses were proposed:

Hla: under environmental regulations, environmental subsidies increase investment of pollution enterprises to environmental protection.

HIb: under environmental regulations, environmental subsidies decrease investment of pollution enterprises to environmental protection.

On this basis, we also noticed that many studies have discovered different influences of government on investment of enterprises to environmental protection. In this study, heterogeneous influences of ownership of enterprises and the technological background of senior executives were further analyzed.

State-owned enterprises are under the control of the government and they are the direct influencing objects of government. Compared with private enterprises, state-owned enterprises have natural relations with the government and they are easier to get more policy supports and government resources. State-owned enterprises concern more on investment in environmental protection under influence of the government (Guo et al. 2016). This is because senior executives of state-owned enterprises who are usually selected through political programs prefer to cooperate with the state to complete scientific research plans, realize the goal set by the government and avoid violation of environmental regulations when they are making strategic decisions within the tenure, thus enabling to assure their promotions. However, the high concentration of stock rights in state-owned enterprises and structural redundancy of organizations are extremely easy to cause low initiatives and efficiency in investment. Jin et 
al. (2018) pointed out that the positive effects of government intervention on private enterprises become more significant. Based on the above analysis, the effects of government intervention on state-owned enterprises and private enterprises vary due to "political" advantages. Therefore, we propose the following hypotheses:

H2a: under environmental regulations, the promotion effect of environmental subsidies on investment of stateowned enterprises to environmental protection is stronger.

$H 2 b$ : under environmental regulations, the promotion effect of environmental subsidies on investment of private enterprises to environmental protection is stronger.

When selecting implementing objects of policies, the government makes decisions according to some explicit signals to avoid interferences of information asymmetry. Specifically, the technological background of the senior executive team of enterprises is a key concern of government (Giannetti et al. 2015). According to the upper echelons theory, the different types of characteristics of senior executives may bring different effects. Senior executives with technological backgrounds prefer more to learn and understand the latest dynamics of the industry. During resource allocation, they may give more investments consciously to cope with constraints of environmental regulations in advance. Besides, the senior executive team with professional background and experience has a more scientific control program and estimation of risk premiums when formulating strategies for investment in environmental protection (Han 2021). Therefore, enterprises have to manifest their qualities and attitudes toward environmental protection when acquiring scarce environmental subsidies. Here, we propose the following hypothesis:

H3: under environmental regulations, environmental subsidies have positive promotion effects on enterprise investment to environmental protection where senior executives have technological background.

\section{METHODOLOGY}

\section{Modeling}

This study aims to evaluate the influences of environmental subsidies on enterprise investment in environmental protection under environmental regulations. The core of policy assessment is to answer the counterfactual problem: if the object of intervention is not intervened, are there any differences in their performances? If objects are selected completely randomly, without any bias error, the difference of investment to environmental protection between the intervened enterprises before intervention and the practically non-intervened enterprises is 0 under the counterfactual conditions. However, this is not random in reality (Bai et al.
2019, Boeing 2016). To solve sample selection bias in policy evaluation, the propensity matching method (PSM) (Rosenbaum et al. 1983) is widely applied to empirical studies.

The matching process is performed according to the following steps:

Step 1: Key influencing factors of environmental subsidies are recognized by the logit model.

$$
T_{i}=\operatorname{Logit}\left(\beta X_{i}+\varepsilon_{i}\right)
$$

$T$ is a binary variable. If the enterprise $\mathrm{i}$ is intervened, $T$ is 1 ; otherwise, $T$ is $0 . X$ is a vector matrix that contains a group of enterprise covariates, $\beta$ is a coefficient vector, and $\varepsilon$ is an error term.

Step 2: Estimate the probability that enterprise $i$ is intervened, which is the tendency score of enterprise $i . P\left(X_{i}\right)$ can be estimated through a probability model:

$$
P\left(X_{i}\right)=\operatorname{Pr}\left(T_{i}=1 \mid X_{i}\right)
$$

Step 3: match sample enterprises by the nearest neighbor matching method based on tendency score:

$$
C\left(P_{i}\right)=\min \left\|P_{i}-P_{j}\right\|
$$

$i$ and $j$ are intervened enterprises and non-intervened enterprises. $C(P)$ represents the neighborhood relationship between $i$ and $j$. When $C(P)$ is the minimum, enterprises $i$ and $j$ are matching mutually.

Finally, influences of government on investment of pollution enterprises to environmental protection, that is, average treatment effect (ATT), can be calculated as follows:

$$
\begin{gathered}
A T T=E\left(Y_{i}-Y_{j} \mid T_{i}=1\right)=E\left(Y_{i} \mid T_{i}=1, P\left(X_{i}\right)\right) \\
-E\left(Y_{j} \mid T_{j}=0, P\left(X_{j}\right)\right)
\end{gathered}
$$

$y$ is an outcome variable, which is the investment of pollution enterprises in environmental protection in this study. Meanings of other variables and parameters are the same as above. The significantly positive ATT means that government influences investment of pollution enterprises to environmental protection significantly.

\section{Samples and Data}

In this study, A-share pollution enterprises in Shanghai Stock Exchange and Shenzhen Stock Exchange, China from 2013 to 2019 were chosen as research samples. Regional environmental regulations and economic level data came from China Environmental Yearbook, China Industrial Statistical Yearbook, and China Statistical Yearbook. Financial data of enterprises were collected from the CSMAR database.

To relieve influences of abnormal values, ST enterprises which are treated specially and samples with data missing of 
important variables were eliminated. Finally, 782 enterprises and 5180 valid observation values were gained as the final samples. Among them, state-owned enterprises account for $52.49 \%$ and private enterprises account for $47.51 \%$. Enterprises where senior executives have technological background account for $86.04 \%$ and enterprises where senior executives have no technological background account for $13.96 \%$. To eliminate influences of extremums, Winsorize treatment was performed on all continuous variables on the $1 \%$ and $99 \%$ levels. All data processing used the STATA15 software.

\section{Definition of Variables}

In this study, there are three major variables, including environmental regulations, environmental subsidies, and enterprise investment in environmental protection. Definitions of these three variables are listed in Table 1.

Environmental regulations: in this study, environmental regulations are measured by the finished investment amount of industrial pollution governance per unit output in different regions (Yuan et al. 2017). Pollution governance investment reflects the degree of government's concern to the local environment and its determination in pollution control problem, and it reflects the intensity of local environmental regulations. This index indicates that given the same total industrial output, the ratio increases, and the regional environmental regulations are stronger with the increase of industrial pollution governance investment.

Environmental subsidies: annotations in the annual reports of listed companies disclose information about environmental subsidies, which are listed in details of government-subsidized projects. In this study, information was organized manually according to keywords related to environmental protection, such as green, emission reduction, environment, sustainability, cleaning, energy conservation, etc. (Bai et al. 2019, Han 2021). All amounts were added to get the total amount of environmental subsidies. The total assets of enterprises were deflated to control scale differences among enterprises.

Enterprise investment to environmental protection: annotations in the annual report of listed enterprises disclose expenses for environmental protection, which are listed in details of the project under construction and management costs. In details of the project under construction, there are capitalization expenses for wastewater and waste gas governance, expenses for energy, water and electricity conversation, expenses for desulfurization, denitrogenation and denitrification, the expense for refuse disposal, expenses for waste heat recovery and utilization, expenses for monitoring system, etc. Details of management cost include fees for sewage charge and afforestation. These expenses which are directly related to environmental protection are added to get the total enterprise investment to environmental protection. The total assets of enterprises were deflated to control scale differences of enterprises (Xie et al. 2018, Zhang 2013).

To assure the effectiveness of the matching process between intervened enterprises and non-intervened enterprises, it is necessary to accurately estimate the probability that enterprises are intervened and adopt some relevant variables that can reflect characteristics of enterprises to strengthen the matching effect. According to existing studies, 6 variables were chosen in sample matching, including enterprise-scale, financial leverage, ownership and technological background of senior executors, regional environmental regulations as well as regional economic level.

\section{RESULTS ANALYSIS AND DISCUSSION}

\section{Influencing Factors of Environmental Subsidies}

Influencing factors of environmental subsidies to enterprises were recognized based on the logit model (Table 2). According to regression results, only the constant term fails to reach

Table 1: Definitions of variables.

\begin{tabular}{|lll|}
\hline Name of variables & Codes & Specifications of calculation \\
\hline Investment in environmental protection & Epi & (investment amount to environmental protection/total assets) $\times 100 \%$ \\
Environmental subsidies & Efund & (Received environmental subsidies of enterprises/ total assets) $\times 100 \%$ \\
Regional environmental regulations & Rule & (Investment amount for per unit industrial pollution governance in a region) $\times 100 \%$ \\
Enterprise-scale & Size & Ln (total assets) \\
Financial leverage & Lev & (Gross liabilities/total assets) $\times 100 \%$ \\
Ownership of enterprises & State & 1 for state-owned enterprises and 0 for private enterprises \\
Technological background of senior ex- & Tback & It values 1 if the president or general manager has technological background; otherwise, \\
ecutives & & it values 0. \\
Regional economic level & Gdp & Ln (regional GDP) \\
\hline
\end{tabular}


the significance level of $10 \%$ and all variation coefficients are significantly $5 \%$ or higher levels. In particular, the coefficient of environmental regulations is the highest, which is 7.349 and reaches the $1 \%$ significance level. This indicates that variable setting is reasonable in this study. Generally speaking, private enterprises which have a relatively smaller asset scale, lower financial leverage, the technological background of senior executives and higher economic development level and locate in places with strict environmental regulations are more likely to get environmental subsidies.

\section{Treatment Effects}

Before estimation of propensity matching, it is necessary to have a matching balance test of pairs. It can be seen from Table 3 that after matching processing, the normalized deviations (\% reduct) of variables decrease to lower than $10 \%$. According to all t-test results, there's no significant difference between intervened enterprises and non-intervened enterprises, indicating that the selected matching covariates and matching method are appropriate. After matching of

Table 2: Influencing factors of environmental subsidies.

\begin{tabular}{|ll|}
\hline Variable & Whether an enterprise obtains environmental funds (=1 for yes) \\
\hline Size & $-0.0817^{* * *}$ \\
& $(-5.38)$ \\
Lev & $-0.7454^{* * *}$ \\
& $(-3.82)$ \\
State & $-0.3480^{* * *}$ \\
& $(-3.77)$ \\
Tback & $0.3776^{* * *}$ \\
& $(3.55)$ \\
Rule & $7.349^{* * *}$ \\
& $(14.22)$ \\
Gdp & $0.1180^{* * *}$ \\
& $(3.73)$ \\
cons & 0.3617 \\
& $(0.55)$ \\
\hline
\end{tabular}

Notes: Data in brackets are $\mathrm{Z}$ statistics. *, ** and $* * *$ indicate the $10 \%, 5 \%$ and $1 \%$ significance levels, respectively

Table 3: Balance test.

\begin{tabular}{|c|c|c|c|c|c|c|c|}
\hline \multirow[t]{2}{*}{ Variable } & \multirow{2}{*}{$\begin{array}{l}\text { Unmatched } \\
\text { Matched }\end{array}$} & \multicolumn{2}{|c|}{ Mean } & \multicolumn{2}{|c|}{$\%$ reduct } & \multicolumn{2}{|c|}{$t$-test } \\
\hline & & Treated & Control & \%bias & bias & $t$ & $\mathrm{p}>|t|$ \\
\hline \multirow[t]{2}{*}{ Size } & $\mathrm{U}$ & 22.1 & 22.54 & -28.9 & & -8.46 & 0.000 \\
\hline & M & 22.1 & 22.15 & -3.3 & 88.7 & -1.42 & 0.157 \\
\hline \multirow[t]{2}{*}{ Lev } & $\mathrm{U}$ & .4600 & .5298 & -31.2 & & -8.45 & 0.000 \\
\hline & M & .4600 & .4479 & 5.4 & 82.6 & 0.67 & 0.546 \\
\hline \multirow[t]{2}{*}{ State } & $\mathrm{U}$ & .5055 & .7008 & -40.7 & & -10.67 & 0.000 \\
\hline & M & .5055 & .5083 & -0.6 & 98.6 & -0.22 & 0.823 \\
\hline \multirow[t]{2}{*}{ Tback } & $\mathrm{U}$ & .8799 & .8023 & 21.3 & & 6.07 & 0.000 \\
\hline & M & .8799 & .8666 & 3.7 & 82.8 & 1.61 & 0.107 \\
\hline \multirow[t]{2}{*}{ Rule } & $\mathrm{U}$ & .1903 & .1290 & 72.9 & & 19.23 & 0.000 \\
\hline & M & .1903 & .1863 & 4.8 & 93.5 & 1.56 & 0.120 \\
\hline \multirow[t]{2}{*}{ Gdp } & $\mathrm{U}$ & .1823 & .4703 & -20.1 & & -6.75 & 0.000 \\
\hline & M & .1823 & .2048 & -1.6 & 92.2 & -1.07 & 0.287 \\
\hline
\end{tabular}


tendency scores, there's no significant difference between the intervened enterprise samples and non-intervened enterprise samples. According to equilibrium hypotheses, the estimation results of tendency score matching on this basis are credible.

After matching, ATT of intervention can be estimated by evaluating differences between intervened enterprises and non-intervened enterprises. It can be seen in Table 4 that $t$-value is 2.85 and it is significant on the $1 \%$ level. According to the significantly positive differences of investment to environmental protection, environmental subsidies facilitate enterprise investment to environmental protection significantly under fixed environmental regulations. ATT between enterprises with and without environmental subsidies is 0.2253 . The investment of enterprises with environmental subsidies to environmental protection is $18.79 \%$ higher than that without environmental subsidies. Therefore, H1a is verified.

\section{HETEROGENEITY ANALYSIS}

\section{Ownership}

According to the results in Table 5, the estimated coefficient of state-owned enterprises is 5.12 and it is significant on the $1 \%$ level. The estimated coefficient of private enterprises is 1.88 and it is only significant on the $10 \%$ level. The investment of state-owned enterprises with environmental subsidies to environmental protection is 0.3978 (58.5\%) higher than that without environmental subsidies and the investment of private enterprises with environmental subsidies to environmental protection is $0.2115(14.11 \%)$ higher than that without environmental subsidies. This demonstrates that given the current environmental regulations, environmental subsidies increase investment of state-owned enterprises and private enterprises to environmental protection significantly. In contrast, state-owned enterprises show higher significance levels, quantities and amplitudes than private enterprises, thus verifying $\mathrm{H} 2 \mathrm{a}$. As an important pillar of the national economy, the state-owned enterprises become the representatives of the state's willingness to green development due to their political connection with the government. These factors facilitate state-owned enterprises to increase investment in environmental protection. Without political advantages, private enterprises face greater pressures of market competition and financing constraints and they must invest more human resources and capital in market profits. Besides, private enterprises are more passive in investment in environmental protection, and are difficult to increase investments in environmental protection, without touching the bottom line of environmental regulations.

\section{Technological backgrounds of senior executives}

It can be seen from Table 6 that when senior executives have the technological background, investment of enterprises with environmental subsidies to environmental protection is 0.4937 (50.13\%) higher than that of enterprises without environmental subsidies and the estimated coefficient is 6.85 , which is significant on the $1 \%$ level. When senior executives have no technological background, investment of enterprises with environmental subsidies to environmental protection is $0.2245(31.15 \%)$ higher than that of enterprises without environmental subsidies and the estimated coefficient is 1.59 , which doesn't reach the significance level of $10 \%$. This indicates that enterprises, where senior executives have technological backgrounds, have stronger tendencies to invest in environmental protection and they are more willing to improve environmental governance levels and even exceed requirements of environmental regulations by

Table 4: ATT of environmental subsidies on investment in environmental protection.

\begin{tabular}{|llllllll}
\hline Variable & Sample & Treated & Controls & Difference & S.E. & T-stat \\
\hline \multirow{2}{*}{ Efund } & Unmatched & 1.424 & .9531 & .4718 & .0664 & 7.10 \\
& ATT & 1.424 & 1.199 & .2253 & .0790 & $2.85^{* * *}$ \\
\hline
\end{tabular}

Notes: $* * *$ and $* * *$ indicate significance levels of $10 \%, 5 \%$ and $1 \%$, respectively.

Table 5: Enterprise grouping based on ownership.

\begin{tabular}{|c|c|c|c|c|c|c|}
\hline & Sample & Treated & Controls & Difference & S.E. & $t$-stat \\
\hline \multirow[t]{2}{*}{ State-owned enterprises } & Unmatched & 1.077 & .9338 & .1440 & .0896 & 1.61 \\
\hline & ATT & 1.077 & 6800 & .3978 & .0777 & $5.12^{* * * *}$ \\
\hline \multirow[t]{2}{*}{ Private enterprises } & Unmatched & 1.710 & 1.458 & .2521 & .1254 & 2.01 \\
\hline & ATT & 1.710 & 1.499 & .2115 & .1128 & $1.88^{*}$ \\
\hline
\end{tabular}

Notes: $*, * *$ and $* * *$ indicate significance levels of $10 \%, 5 \%$ and $1 \%$, respectively. 
Table 6: Enterprise grouping according to the technological background of senior executives.

\begin{tabular}{|lllllcr|}
\hline & Sample & Treated & Controls & Difference & S.E. & $t$-stat \\
\hline Senior executives & Unmatched & 1.478 & 1.403 & .0745 & .0874 \\
has technological background & ATT & 1.478 & .9847 & .4937 & .0721 \\
Senior executives & Unmatched & .9451 & .7025 & .2426 & .1798 \\
has no technological background & ATT & .9451 & .7205 & .2245 & .1408 \\
\hline
\end{tabular}

Notes: *,** and $* * *$ indicate significance levels of $10 \%, 5 \%$ and $1 \%$, respectively.

taking advantage of their professional after getting environmental subsidies, thus enabling to avoid reputation loss and economic cost for violating environmental regulations. As a result, it is very necessary to distinguish whether senior executives have technological backgrounds or not to discuss environmental subsidies. Hence, $\mathrm{H} 3$ is verified.

\section{CONCLUSIONS}

To address the heavy environmental pollution problems, the government not only implements strict environmental regulations but also increases environmental subsidies to enterprises. Based on data of pollution enterprises in the capital market from 2013 to 2019 , the influences of the government's environmental subsidies on enterprise investment to environmental protection under environmental regulations were discussed by PSM. Moreover, heterogeneity influences of ownership of enterprises and technological background of senior executives were analyzed. Conclusions could be drawn:

1. Asset scale, liability level, ownership, the technological background of senior executives and environmental regulations and economic levels of local areas of enterprises are key factors that influence pollution enterprises to get environmental subsidies. Among them, environmental regulations show the maximum degree of influence.

2. Environmental subsidies stimulate pollution enterprises to increase investment in environmental protection significantly. The investment of enterprises with environmental subsidies to environmental protection is $0.2253(18.79 \%)$ higher than that without environmental subsidies.

3. Environmental subsidies increase investments of both state-owned enterprises and private enterprises to environmental protection significantly. In particular, the quantity and growth of investment of state-owned enterprises to environmental protection are more prominent.

4. Environmental subsidies significantly facilitate enterprises where senior executives have the technological background to increase investment in environmental protection. However, environmental subsidies show no significant impacts on enterprises where senior executives have no technological background.

Concerning policy enlightenments, the empirical evidence in this study can provide the following references to relevant government sectors and enterprises:

To stimulate pollution enterprises to increase investment in environmental protection effectively, the government shall continue to implement strict environmental regulations, strengthen deterrence by punishment and approval of industrial access, completely eradicate the fluke mind of enterprises, and adopt emergency environmental governing to cope with environmental supervision of the government. On one hand, the government also shall continue to increase environmental subsidies to pollution enterprises and offset environmental protecting and financing gaps of enterprises. On the other hand, the government shall establish diversified social financing mechanisms and relieve excessive dependence on government resources. During implementation and environmental protection funding policies, government shall generally make full use of collaborative effects of relevant laws and subsidies enterprise investment to environmental protection.

Pollution enterprises shall focus on long-term development and envisage the social-economic effect of improving environmental protection performances. Given high concerns of the government to strict environmental regulations, pollution enterprises shall increase investment to reconstruction of environmental protection technologies and equipment from the production source, adopt clean production modes, decrease pollutant discharges, get supports of government and approval of all involved social stakeholders, and avoid punishment for violating environmental regulations.

It has to point out that increasing investment of pollution enterprises to environmental protection is just one aspect to measure environmental performances and it is only a requirement rather than a sufficient condition to evaluate the validity of environmental subsidy policies. The government also shall concern whether the output index of enterprises is improved to some extent after investment in environmental protection. The external compulsive effect of environmental protection regulations also has limitations. In a word, the 
government shall establish a scientific performance evaluation system of environmental protection capital policy, including early investment evaluation, late economic benefit evaluation, social benefit evaluation, and environmental benefit evaluation. Moreover, the government shall not only design a reasonable and comprehensive analysis and evaluation system, but also set up a reasonable and effective policy support model for different types of enterprises, and develop the collaborative effect of policies to the maximum extent.

\section{ACKNOWLEDGMENT}

This study was supported by the Soft Science Project of Henan Province in China (No. 182400410659), the Doctoral Foundation Project of Henan University of Engineering (No. D2017027), and the General Project of Humanities and Social Sciences Research for Universities and Colleges in Henan Province (No. 2022-ZDJH-00272).

\section{REFERENCES}

Bai, Y., Song, S., Jiao, J. and Yang, R. 2019. The impacts of government $\mathrm{R} \& \mathrm{D}$ subsidies on green innovation: Evidence from Chinese energy-intensive firms. Journal of Cleaner Production, (233): 819-829.

Boeing, P. 2016. The allocation and effectiveness of China's R\&D subsidies: Evidence from listed firms. Research Policy, 45(9): 1774-1789.
Giannetti, M., Liao, G. and Yu. X. 2015. The brain gain of corporate boards: Evidence from China. Journal of Finance, 70(4): 1629-1682.

Guo, D., Guo, Y. and Jiang, K. 2016. Government-subsidized R\&D and firm innovation: Evidence from China. Research Policy, 45(6): 1129-1144.

Han, C. W. 2021. Impact of environmental subsidies on environmental technology innovation of polluting enterprises. Nature Environment and Pollution Technology, 20(3): 1277-1284.

Jin, Z. J., Shang, Y. and Xu, J. 2018. The impact of government subsidies on private R\&D and firm performance: Does ownership matter in China's manufacturing industry? Sustainability, 10(7): 2205.

Li, D., Zheng, M., Cao, C., Chen, X., Ren, S. and Huang, M. 2017. The impact of legitimacy pressure and corporate profitability on green innovation: Evidence from China top 100. Journal of Cleaner Production, (141): 41-49.

Pellegrino, C. and Lodhia, S. 2012. Climate change accounting and the Australian mining industry: Exploring the links between corporate disclosure and the generation of legitimacy. Journal of Cleaner Production, (36): 68-82.

Rosenbaum, P. R. and Rubin, D. B. 1983. The central role of the propensity score in observational studies for causal effects. Biometrika, 70(1): 41-55.

Xie, Z. H., Sun, Y. X. and Wang, Y. 2018. The influence of environmental regulation on corporate environmental investment of companies: A panel data study based on heavy pollution industry. Journal of Arid Land Resources and Environment, (3):12-16.

Yuan, L. J. and Zheng, X. F. 2017. Coupling induction of environmental regulation and government subsidy on enterprise technological innovation. Resources Science (5): 911-923.

Zhang, G. F. 2013. Government intervention, environmental pollution and corporate environmental protection investment: Evidence from listed companies of heavy pollution industries. Research on Economics and Management, (9): 38-44. 